\title{
Od redaktorów
}

Przedstawiana Czytelnikowi monografia zatytułowana Mikrotoponimy i makrotoponimy w komunikacji i literaturze jest drugą publikacją wydawaną w ramach projektu Nomina loci pod auspicjami Komisji Onomastyki Słowiańskiej przy Międzynarodowym Komitecie Slawistów. Cała seria jest pokłosiem rozważań podjętych podczas XVIII Międzynarodowej i Ogólnopolskiej Konferencji Onomastycznej „Mikrotoponimia i makrotoponimia” (Łódź, 27-29.10.2012).

Pierwsza z książek w tym cyklu ukazała się pt. Mikrotoponimia i makrotoponimia. Problematyka wstęnna (red. Artur Gałkowski, Renata Gliwa, Łódź 2014). Niniejsza monografia, podobnie jak poprzednia w serii, zawiera kilkadziesiąt rozdziałów napisanych w kilku językach (polskim, słowackim, czeskim, ukraińskim, włoskim, francuskim, angielskim) przez autorów pochodzących z różnych ośrodków naukowych Polski i Europy, głównie Europy Wschodniej. Każdy tekst opatrzony jest krótkim streszczeniem w języku angielskim. Poszczególni autorzy rozpatrują jednostki nazewnicze (głównie mikrotoponimy) pod kątem ich występowania, użyć i funkcji w różnych planach komunikacji. Za odrębny w formie uznajemy obszar literatury, stąd wyodrębnienie go zarówno w tytule książki, jak i jej podziale na „Przestrzeń komunikacyjną” i „Przestrzeń literacką”. W studiach zamieszczonych w części pierwszej autorzy podejmują tezy, których celem jest analiza toponimów (mikro- i makrotoponimów) pod względem formalnym, pragmatycznym i kulturowym. Tu też odniesienie do sfer komunikacji medialnej, a mianowicie Internetu i prasy. Część druga zamyka się w kręgu metodologii onomastyki literackiej. W posłowiu zamieszczono wspomnienie o zmarłym w $2012 \mathrm{r}$. Profesorze Vincencie Blanárze, nestorze słowackiej i słowiańskiej onomastyki.

Wyrażamy przekonanie, że publikacja wnosi do badań nad mikro- i makrotoponimią zarówno tradycyjny, jak i nowy sposób ich postrzegania w studiach onomastycznych, szerzej zaś - komunikacyjnych. 



\section{Editors' notes}

The monograph Microtoponyms and macrotoponyms in communication and literature presented to readers, is a second publication issued as a part of the Nomina loci project under the auspices of the Slavic Onomastics Committee by the International Board of Slavists. The whole series is the outcome of deliberations started during the $18^{\text {th }}$ International and Polish Onomastics Conference "Microtoponyms and macrotoponyms" (Łódź, October 27 - 29, 2012).

The first of the books of this series was published under the title: Microtoponyms and macrotoponyms. Preliminary problems (editors: Artur Gałkowski, Renata Gliwa, Łódź 2014). This monograph, similarly like the previous one in this series, contains several dozen of chapters written in several languages (Polish, Slovak, Czech, Ukrainian, Italian, French, English) by authors from different scientific centres in Poland and Europe mainly Eastern Europe. Each text includes a short summary in English. Individual authors consider nomenclature units (mostly microtoponyms) as to their existence, uses and functions in different communication plans. Literature area is considered as separate in form, hence its distinction both in the title of the work as well as its division into "communication space" and "literary space". Studies included in the first part analyse theses whose aim is to consider toponyms (micro- and macrotoponyms) as to their formal, pragmatic and cultural character. The work also contains references to media communication areas, and most specifically to the Internet and press. The second part discusses literary onomastic methodology. The afterword contains posthumous tribute to Professor Vincent Blanár, a doyen of Slovak and Slavic onomastics, deceased in 2012.

We wish to express our belief that this publication introduces both traditional as well as a new way of perceiving micro- and macro research in onomastic studies, or broadly speaking - in communication studies. 